\title{
On Being a Tranggender Man in the Czech Pagan COMMUNITY
}

Giuseppe Maiello, University of Finance and Administration, Prague Kamila VelкoborsKá, Independent researcher, Pilsen

\begin{abstract}
This paper presents a specific situation concerning the Czech Pagan community, mainly through the narrative of their members. Using the emic approach, the aim of this paper is to show an insider's perspective of the ways in which Czech Pagans relate to transgender issues and its connection with the vaguely understood concept of shamanism. Due to the problematic nature of the informants' experience, the paper uses the narrative interview and episodic narrative interview approaches. Free narration enabled the interviewee to use their own spontaneous language to tell stories of their life with minimal influence from the interviewer.
\end{abstract}

KEYWORDS: transgender, neopaganism, shamanism, gender studies, qualitative research, Czech Republic.

\section{INTRODUCTION ${ }^{1}$}

Unlike in American Paganism, where transgender identity has recently become the subject of much interest, the Czech "Pagan" community is virtually silent on the topic due to its small size. Apart from the occasional (and popular) workshop given by the transgender man and shaman Raven Kaldera, not much is known regarding transgender pagan people. ${ }^{2}$ There are no major public Pagan events with rituals where transgender Pagans have been denied entry, nor groups open exclusively to ciswomen and cismen. In fact, there are no transgender Pagans who would demand entry into such exclusionist rituals or groups. To our knowledge, there is only one visibly transgender Pagan man - who for the purposes of our study we will call Weeho (aged 42) -, some perceive him as a mystical figure but most do not acknowledge or consider him to be any more special or deserving of attention than anyone else in the community.

It should be also emphasized that until the end of the last century the Czech Republic, like the majority of pagan communities, was not at all affected by themes of "Western" origin

\footnotetext{
${ }^{1}$ This text was created as output within the grant project Mother and father? Nonbinary and transgender families in the Czech Republic: a legislative norm and the ideas of NB/TG people (no. 7427/2021/05) using objective oriented support for specific university research of the University of Finance and Administration.

${ }^{2}$ Raven Kaldera spent 6 days in the Czech Republic until 16 May 2011 (Raven Kaldera's personal information). Raven Kaldera's bibliography concerning paganism (Northern tradition) and transgender identity is extremely rich (see in particular Blank-Kaldera 2002, Kaldera 2007a, b; Kaldera 2008; Kaldera 2010; Kaldera 2012a, b; Kaldera-Krasskova 2012, Filan-Kaldera 2013). The only book by Kaldera translated into Czech is MythAstrology (2006).
} 
proposed in the context of feminist activism (Osvaldová 2004). ${ }^{3}$ It is most likely for this reason as well that neither the Wicca nor organizations such as Pagan Federation International have ever reached a level of diffusion or organization in the Czech Republic comparable to that of local neopagan groups that arose independently of Western cultural impulses. ${ }^{4}$ All the discussion around Queer Paganism that has appeared even at academic levels is either completely unknown or ignored in the Czech Republic. This is a feature common to all other Central-Eastern European countries, where the conservatism of the regimes in power managed to create a massive barrier, at least until 1989, to the spread of Western feminist ideas, creating a social attitude of repulsion toward all related issues, such as those related to gender and sexuality. Even Czech pagan groups, therefore, cannot yet be fully considered similar to Western ones despite intrinsic efforts to distinguish themselves from the social attitudes believed to be dominant. ${ }^{5}$

The goal of this paper is to capture the points of interconnection between Weeho's transgender identity and his religious practice. The perspectives of other members of the Czech Pagan community will be taken into account.

\section{Methods}

To achieve our goal, we will use - in addition to field data - publications by transgender Pagans themselves, the best-known being chapters from the book Gender and Transgender in Modern Paganism (Thompson, et al. 2012) and the works of the American Nordic-tradition shaman Raven Kaldera. These will serve as a source of inspiration in our own research, based on the insiders' narratives, which will help us decide whether the problems dealt with by transgender Pagans in the USA relate in any way to our field.

As the Czech Pagan scene is extremely small, we cannot offer a fair sample of examples for comparison, and it is certainly not our objective to reach any substantial far-reaching conclusions. Instead, we will use the strategy known as ethnography of the particular to see how - at least on the Czech Pagan scene - an individual's gender identity is connected to their religious practice.

Because of the smallness of the Czech pagan scene, we do not make any specification of towns and villages; most Czech Pagans know each other and travel across the Republic for festivals and other sacral meetings. We also acknowledge that the term "Pagan” is not appropriate, as it is not generally accepted by all individuals identifying with forms of religion

\footnotetext{
${ }^{3}$ Although the Czech lands have been deeply anchored in Western culture since the Middle Ages, gender issues have been strongly ostracized in social discourse after the Second World War. The almost non-reaction of Czech society to the terrible experience suffered by dozens of sexually outraged young women by the youngest of Czech politicians (and at the same time the most famous Czech instagram influencer), which came to light in some independent media in the spring of 2021 (see Rychlíková-Zelenka 2021), leads us to think that on gender issues the Czech Republic is still lagging behind older CEE European countries and the United States. For this reason we believe it is necessary, from the etic perspective, to make a distinction between "Western" countries and "Central-Eastern European" countries.

${ }^{4}$ There is a well-maintained website of the Bohemia-Moravian-Silesian section of Pagan Federation International. However, the "events" section contains merely a Czech text that can be translated as "Sadly, we don't have any events at the moment" (http://www.pohanskafederace.cz/akce-pficz/). As far as Wicca is concerned, there are very few initiations that take place outside the national territory.

${ }^{5}$ As showed in Aiamurto-Simpson (2014), and specifically for Czech slavic contemporary paganism in Maiello (2015). Even the correct clarifications offered by Christine Hoff Kraemer $(2012,2016)$ can only apply to the North American and Western European context.
} 
alternative to monotheism. However, in the absence of a more appropriate term, we have opted to continue to use the term „Pagan” given its acceptance by all of our informants.

As regards the ethnography of the particular, our objective is to focus on the characteristics, lifestyle, and thought-world of a person, without any claim to draw generalizations from the particular (see Abu Lughod 1991; Han-Cunha 2017; see also Ruggiu 2012, 201).

By using the episodic narrative interview method, which combines the advantages of narrative and guided interviews ${ }^{6}$ the informants revealed not only the story of a particular experience as preserved in their memory (times, places, situations, and other participants) but also the semantic knowledge attached to this particular experience. It has been confirmed that telling stories prompts the interviewee to express their particular perspective in a more genuine form than when they are manipulated into answering specific questions using a question-response schema method.

The data used in this paper come from long-term fieldwork and participant observation of the groups to which our subject belonged. This research was conducted independently at different points in time, between September 2013 and February 2015. To obtain a deeper insight into the issues of transgenderism and neo-shamanism we have conducted a number of unstructured and semi-structured interviews with Weeho and several members of his present community, as well as people from outside his community who know him from Pagan events open to all communities.

As the number of pagan communities in the Czech Republic is very limited and the members of the communities know each other, we decided to not provide any specific data on the structure, organization, or ritual peculiarities of the community studied so that no one will be able to recognize where Weeho operates.

The interviews were conceived as unstructured in order to build a better rapport with the interviewees.

\section{INSPIRATION}

The initial chapters of the book Gender and Transgender in Modern Paganism deal with transphobia at the PantheaCon 2010, an annual American conference for Pagans, Heathens, and Indigenous Non-Europeans attended by over 2,000 people and featuring more than 200 presentations, rituals, workshops, classes, and concerts. The contributors participating at the event criticized the organizers of particular women's rituals for "checking to make sure that no one who wasn't born with female genital equipment at birth could enter their rituals" (Moonwater 2012, 5). They based their criticism on the idea that „we pagans, who call ourselves Earth-worshippers, who profess to be inclusive of all and empowering of all, were not" (Pond 2012, viii). The strategy used by the organizers was seen as an act of hypocrisy, misogyny, and misandry.

Events of this size that produce controversies this big are unimaginable in the Czech Republic, and the issue of refusing admission to public events therefore goes beyond our scope of interest. What interests us is the way in which one's gender is perceived and handled. The perception of one's gender ranges from considering it completely irrelevant to religious

\footnotetext{
${ }^{6}$ The narrative interview is a qualitative research method elaborated by the German sociologist Fritz Schütze (1977). The method was then developed in the nineties under another German sociologist, Gabriele Rosenthal (1995). The episodic narrative interview method is a modification of the interview narrative approach developed by another German sociologist, Uwe Flick (see Flick 1995). The first translation of the seminal work by Uwe Flick into English, titled 'An Introduction to Qualitative Research' dates back to 1998 (see Flick 1998). In the Czech speaking ambit the narrative and episodic narrative interview approaches have been explained at length by Jan Hendl (2005)
} 
practice to believing that gender identity is key to one's religious practice. We found both positions represented in the book:

I am a witch and a ceremonial magician. I co-lead a coven in the Alexandrian tradition, and I am an initiate of the Golden Dawn tradition, with a particular specialism in magical toolmaking, theurgy and goety. I also happen to be a transsexual woman. It feels very strange to write that because I happen to regard it as probably the least interesting thing that anyone might know about me, because it simply doesn't concern anyone but myself and perhaps my partners. It's certainly not anyone else's business, beyond that very small group (Thompson 2012, 1).

I am a shaman in the Northern tradition... I am a particular type of shaman... There is some debate about exactly how that should be defined historically but anthropologically it's part of the same package as the male-bodied Siberian shamans ... who wore skirts, took husbands, and channeled female spirits as part of their spiritual path. When scholars... have interviewed gender-crossing spirit-workers around the world, they ask them why they did it... and the answer is never "I was uncomfortable in my body." ... it tends to be "The spirits told me that I had to do it or I would die" (Kaldera 2012, 75).

While Sarah Thompson claims her gender identity is unconnected to and irrelevant to her spiritual practice, Raven Kaldera, born intersex, raised as a woman, and having chosen to present himself as a man when he was 30, gives explicit reasons for the change of his gender identity. These reasons are spiritual: the gods and spirits told him that he had to do it and therefore:

... my gender situation is entirely wound up with my religious beliefs and practices (Kaldera 2012, 75).

As a result, Raven Kaldera presents himself variously as a third-gender shaman or as a representative (and spokesperson) of the sacred third.

\section{Weeho: the Czech CASE}

Weeho, recognized as female at birth, underwent gender-affirming treatment at the age of 25. He was raised as a girl in a family deeply devoted to the Jehovah's Witnesses and his early childhood was marked by the fact that his mother and grandmother, along with other devoted believers, were awaiting the end of the world. The life of the family revolved around the church and its beliefs, rules, and regular activities. As in other cases of people raised in Jehovah's Witness families, Weeho could not go to school.

From his early teens he did not accept his feminine identity. He was made to leave the church upon reaching adulthood due to his inappropriate behavior and mode of dress associated with this refusal to accept his femininity. After some years of searching, he began participating regularly in "American Indian historical re-enactment group activities" ${ }^{\prime 7}$. At the end of the last century, he also joined in the activities of one of the two organized pagan communities active

\footnotetext{
7 "American Indian historical re-enactment groups", in Czech "Indiáni", are communities typical of the Czech underground scene, that have been active for several decades. The name denotes a form of naiveté in the relationship of those communities with the Aboriginal cultures of the northern part of the North American continent.
} 
in the Czech Republic. After that, Weeho followed the destinies similar to those of other Pagan youths, changing communities and organized groups or practicing alone.

He sees sex reassignment as an inevitable step in his life, one that was also deemed necessary by his friends:

Without the physical transformation I could not mature - the adult person acts for himself, he must not play roles (Interview with Weeho, aged 42).

After the final steps of his transition, he started to have visions and became interested in shamanism. These visions did not deal with his physical transformation, however, but with the transformation associated with leaving the church, which seems to have opened new vistas:

I sorted out this thing ${ }^{8}$, they ${ }^{9}$ got rid of me and I searched for my way, e.g. they decided for you (Interview with Weeho, aged 42).

In Weeho's case, the transformation may not have been connected with his spiritual life (with visions and religious practice as such), but it had a practical effect on his subsequent spiritual life - it made that life possible.

Weeho has lived in a caravan and shelters without electricity, under very basic conditions, moving frequently. For this he is both admired (as he is able to survive under all conditions) and criticized (he tends to deal thoughtlessly with the space he inhabits - from an outsider's point of view - given that he does not construct places, but rather destroys them by living in them).

Despite living a largely solitary lifestyle (not sharing a household permanently with anyone), he connects with people, specifically Pagans, by participating in rituals, leading them, and slowly becoming perceived and known as a "shaman", without consciously seeking such status.

\section{How do other pagans perceive Weeho?}

When I first met Weeho, I was unsure of his gender identity due to his delicate physiognomy and rather high-pitched voice. This is the most common impression he makes on people (Interview with Kamcha, aged 43).

He makes a hobbit-like impression but inside I perceive him as a man (Interview with Drago, aged 42).

I was not sure whether he was a man or a woman due to his female sounding voice but then I noticed he was addressed as a man and that was that (Interview with Vlad, aged 33).

He talks in a funny way - that was the only thing that puzzled me... for me he's simply a guy (Interview with Paolo, aged 39).

To be truthful, I was somewhat suspicious - I was not persuaded that he was a man, even though his name was clearly male - but it was never talked about, neither with him, nor among friends (Interview with Rowan, aged 26).

Well, I've known him for some seven years and in that time I've stayed at his place several times, participated in plenty of rituals with him, and discussed plenty of topics with him, but it never

\footnotetext{
${ }^{8}$ i.e. gender-affirming treatment

${ }^{9}$ i.e. the Jehovah's Witnesses
} 
crossed my mind that I could be dealing with a woman... I've always perceived him as a man and I've always talked to him as to a man... (Interview with Ruewolf, aged 30).

When they first meet him, many people hesitate as to what he is exactly... (Interview with Loba, aged 38).

How do people learn about Weeho's gender identity? People usually learn about Weeho's identity indirectly.

I actually learned about the existence of a transgendered pagan in 2006 from my colleague when I interviewed him to get a general picture of Czech paganism. The information had gone out of my head when I met Weeho in person several years later, when I interviewed him and then did several rituals with him. It was only when I saw him bare-chested working in the garden last summer and saw the scars that suddenly everything clicked. That's how people learn about it; either they overhear something in conversation suggesting it or they see the scars and begin to wonder. It is never part of the introduction, it is never spoken of directly or explicitly (Interview with Kamcha, aged 43).

When they do finally learn about his gender identity, how do people react? Does it influence a person's personal feelings towards Weeho or does it influence their perception of him in a ritual context? There are two basic reactions we witnessed. In the first case it is considered irrelevant. In the second case he is perceived as a shaman (because shamans are supposed to be different).

I found out about a year ago that he was originally a woman when it somehow came up in conversation with $A d$, it surprised me a lot but as quickly as the information came, it ... effectively... vanished ... I don't know how to say it... the information was simply completely irrelevant for me... Weeho simply remained a person of male gender, with a male soul and thinking... (Interview with Ruewolf, aged 30).

I've never seen him completely naked but I noticed long ago that he had scars on his chest and my suspicion deepened... when I finally learned how things really are, I was surprised as I have never met a transgendered person before but as I expected, it was not such a big surprise (Interview with Rowan, aged 26).

For me he is simply a shaman (Interview with Vlad, aged 33).

His energy is utterly male and he has a kind of propensity towards shamanic matters, I take him as a shaman... I have a feeling that he has been chosen - the gods have chosen him... this is just a feeling... when I found out that he had undergone surgery, it clicked... I don't need to poke into it any further... (Interview with Paolo, aged 39).

With this accentuation of the simple word "shaman", it seems as if members of the community aspired to have their own shaman, meant only in the sense of someone born with special features. This perception is considered a spark that will launch a deeper belief in shamanism in the Czech Republic, as far we understood from the narratives. It is clear, however, that in this case the aspiration is based on a very vague knowledge of shamanism, ${ }^{10}$ and even in terms of growing interest in shamanism among Pagan groups, given that many young people travel and sometimes also visit Western neopagan communities, where the shamanic theme is taken

${ }^{10}$ The text on shamanism by Mircea Eliade (1950) has been translated into Czech, and the texts by Claude LéviStrauss (1958) and Evelyn Lot-Falk (1974, with Régis Boyer) are also well known, but only by academics. Many texts by Carlos Castaneda (1968, 1971, 1972, 1981, 1987, 1993, and 1998) have also been translated since the late 1990s. The members of the community we studied were mainly aware of this second type of literature, either directly, or from the Czech language magazine Dingir, which devoted a special issue in 2008 on the right to shamanism (see Vojtíšek 2008). 
into greater consideration than it is in the countries of Central and Eastern Europe, the Czech Republic appears to be "behind schedule". The cause may probably derive from the fact that the oldest Czech Pagan groups were formed from searching for identity from a presumed starting ethnicity (Slavic, Germanic, or Celtic), so they confined the debate on shamanism to interest in a cultural field similar but "different „(Siberia, Central America, and more rarely Africa and China). ${ }^{11}$

Shamanism as it pertains to Weeho is then reduced to a possible ability to "communicate with the supernatural" and above all to have a very close relationship with a particular type of animal, e.g., the wolfdog.

Apart from the people stating explicitly that he is a shaman (although they do not neglect to mention several factors that make him a ",not entirely perfect shaman"), all of them, without exception, point out his being different from anybody else.

His unique gender identity is only one factor in his being different, but this factor fits well with what is commonly imagined (within the Czech Pagan community) to be shamanic identity.

He is different from anybody else, a kind of homeless person, hermit - able to take care of himself under all conditions... he is an original. He would be a good shaman, people would come to him and he wouldn't need anybody... he doesn't show much regard for others, he just goes to sleep... he has strange opinions... and a suppressed aesthetic sensibility... the kittens are cute (ท̆uňu) but then he clouts them with a brick... (Interview with Drago, aged 42).

He's a weirdo (Interview with Loba, aged 38).

He is a wandering soul (Interview with Drago, aged 42).

He simply has a good talent for improvisation and an immediate reaction in the case of rituals... at least that's how I always felt... moreover, he is very skilled at manipulating people, perhaps from the school of Jehovah's Witnesses, but this is also sometimes quite useful... and his style of life itself helps the fact that a person can begin to think differently... a bit in the old ways... so he can understand some symbols better, he is more aware of the proximity of the boundary between this world and the world of the gods... which he can then make good use of in the rituals... But this has a dark side too... perhaps Weeho has a bit of an insensitive approach to nature, when in the way of our ancestors he would rather fight with it than harmonize with it... (Interview with Ruewolf, aged 30).

Ok, we could say he is a shaman but he is not what we usually imagine under the title, I guess there is no better word... (Interview with Loba, aged 38).

None of the informants explicitly stated that Weeho's gender identity is a key factor making up his shamanic identity. When asked, people seemed never to have thought about it and are at a loss for words, answering vaguely that perhaps it plays some role, but that he is simply a weirdo, whether man or woman.

I think it plays a role but not a key one... he would be a shaman if he remained a woman or if he was born a man... (Interview with Loba, aged 38).

\footnotetext{
${ }^{11}$ Even the interesting book by Helena Exnerová (2018), which not only provides a summary of the studies on archaic and contemporary shamanism but also presents 9 shamans active in the Czech Republic through deep interviews, did not have a general influence on traditional Pagan groups precisely because shamanism is not yet seen as something on which to base their theəlogical setting.
} 


\section{Weeho about himself}

Other people perceive Weeho as a shaman, a „weirdo”, a person best skilled to travel between the worlds, a chosen one, and a special one - a "transitional being" - but are unable to identify the role of gender identity in being a (kind of) shaman. This is because everything about him seems so strange, unusual, and different that his atypical gender identity merely fits nicely into the whole picture.

He is a mystical figure (Interview with Drago, aged 42).

How does he see himself? Does he draw any magical or spiritual power from having undergone the transformation? Is his being transgender somehow connected with shapeshifting, a commonly perceived prerequisite of being a shaman? These views often occurred in the narratives of our informants, therefore we decided to test them in the interviews with Weeho himself. He says that "this can be an impression formed by the external observer. A power? Not really." He did not seem to understand the question. One of the members of the community tried to find the answer:

I talked and talked and I learned a thousand interesting things but I still did not get the answer I was after and decided to conclude that there is simply no connection, although something in me strongly believed there was (Interview with Kamcha, aged 43).

Two days afterwards, Kamcha received a lengthy text message containing the answer.

Concerning the topic we discussed, it just occurred to me that shamanic or magical skills tend to be considered female. A woman has a womb where new things are created, she takes the power not by the strength of arms but the strength of spirit, you know... a man, if he wants to know magic, has to become a woman... but there is another way - to become damned and without honor ... a werewolf is also a form of transition (SMS by Weeho, aged 42).

At this point, I suggested that he has a double initiation - being a woman and a werewolf (his spiritual work is connected with animals, especially wolves) - but I was mistaken. Weeho said clearly that he was actually the second one. I objected that he has an experience with the womb, and this is the reply I got: "But there was no connection. How to say it? If you woke up tomorrow morning and found out in the mirror that you are a man, you'd gain experience with the dick but it would not necessarily make you a warrior" (Interview with Kamcha, aged 43).

\section{Conclusion}

Weeho does not fit into any tidy categories like "shaman", "transgendered person”, etc., but on the scale we suggested at the beginning leans toward the one where gender identity is irrelevant in spiritual practice. The important things are what are commonly referred to as shamanic skills: the ability to travel between worlds, enter alternative states of consciousness and help others to do the same, lead a ritual, and heal (to an extent). By others he is perceived as a liminal persona, to use Victor Turner's terminology, in the sense that he does not belong anywhere but lives an alternative lifestyle, not needing other people, having abnormal tastes and opinions, behaving strangely, and having unusual physiognomy suggesting both 
masculine and feminine identities. ${ }^{12}$ The fact of the transition is not a constructive factor, but fits in well, completing the picture of the shaman Weeho.

Weeho understands the point of view that his gender is significant from the outside, but he states that the transformational forces that make him who he is spiritually are different from those connected with the change of gender. He never felt ", at home" with his feminine body, which therefore could not be any source of magical or shamanic power. However, the genderaffirming treatment made the development of shamanic identity possible.

The members of the Czech Pagan community who know Weeho - though vague about the connection between gender and spirituality - compare him to Raven Kaldera.

Everybody is crazy about Raven Kaldera but we have one too, and people don't even know about him! (Interview with Drago, aged 42).

I am quite glad that despite his skills and art in spiritual things he has not built his fame like Kaldera on some sexual anomaly... (Interview with Ruewolf, aged 30).

Because Czech Pagans learn about the identity of Weeho indirectly, when they know more about him, they react indifferently or start to consider him a shaman (taking into account, however, that no one explicitly admits that Weeho's gender identity is a key factor making up his shamanic identity). But Weeho does not accept the shaman title completely; rather, he accepts what has been imposed on him from outside. Having successfully removed the memory of having a womb, wolves are his source of spiritual influence today.

As regards his gender identity, he denies its influence on his spiritual life as a formative influence. Rather he sees it as a factor making an authentic life possible and part of that life happens to be spirituality. He does not consider himself a special person worthy of attention (and has no desire for attention) and therefore strictly refuses any comparisons with the wellknown American transgender shaman Raven Kaldera:

... I am not Kaldera! (Interview with Weeho, aged 42).

The refusal to regard himself as the Czech Kaldera is obviously understandable. It incorporates an ethical refusal to consider oneself something that Weeho does not consider part of an indigenous tradition or that at the very least is not sufficiently proven to have a universal character. ${ }^{13}$

On the other hand, however, it should be emphasized that bestowing the name of shaman on a person who has undergone gender-affirming treatment seems to be a way to exorcise this practice; that is, without talking about it openly. It is a category that is still relatively foreign to traditional neopagan groups, but more acceptable than that of the transgender man.

\footnotetext{
${ }^{12}$ The notion of "liminal personae" (threshold people, sing. liminal persona) was introduced in 1967 by Victor Turner. The concept of liminality was later taken up in other fields related to social anthropology, such as political anthropology (see Thomassen 2009) and sociology (see Klein and Williams 2012).

${ }^{13}$ Severe criticisms of the use of shamanism as an umbrella term and of considering shamanism as the "universal primitive religion" were raised, for example, during the 4th International Conference of the International Society for Shamanic Research held at Chantilly in September 1997 (Francfort, Hamayon, \& Bahn 2001). The well-known Italian historian of religions, Giovanni Casadio, also expressed the same critical perspective (2014). It is not at this time for the authors to support any of the theories on contemporary shamanism currently under discussion.
} 
Furthermore, having an alleged shaman within a community operating in the Czech Republic gives it the ability to state that:

... we have a Shaman too (Interview with Drago, aged 42)

and therefore somehow bring Czech pagan spirituality closer to something you hear about when the discourse turns to the perception of the sacred attributed to Western neopagan groups.

\section{REFERENCES}

Aвu-Lughod, Lila. 1991. «Writing Against Culture». In Recapturing Anthropology Working in the Present edited by Fox, Richard G., 137-162. Santa Fe, NM: School of American Research Press.

Aitamurto, Kaarina, and Scott Simpson. 1994. Modern Pagan and Native Faith Movements in Central and Eastern Europe, New York: Routledge.

Blank, Hanne, and Raven Kaldera. 2002. Best transgender erotica, Cambridge, MA: Circlet Press.

Boyer, RÉGIS, And Éveline Lot-FALck. 1974. Les Religions de l'Europe du Nord. Eddas, sagas, hymnes chamaniques, Paris: Fayard-Denoël.

Casadio, Giovanni. 2014. Lo sciamanesimo prima e dopo Mircea Eliade, Roma: Il Calamo.

Castaneda, Carlos. 1968. The Teachings of Don Juan: A Yaqui Way of Knowledge, Oakland CA: University of California Press - New York: Simon \& Schuster.

Castaneda, Carlos. 1971. A Separate Reality: Further Conversations with Don Juan, New York: Simon \& Schuster.

Castaneda, Carlos. 1972. Journey to Ixtlan, New York: Simon \& Schuster.

Castaneda, Carlos. 1981. The Eagle's Gift, New York: Simon \& Schuster.

Castaneda, Carlos. 1984. The Fire from Within, New York: Pocket Books.

Castaneda, Carlos. 1987. The Power of Silence: Further Lessons of Don Juan, New York: Simon \& Schuster.

Castaneda, Carlos. 1993. The Art of Dreaming, New York: HarperCollins.

Castaneda, Carlos. 1998. The Practical Wisdom of the Shamans of Ancient Mexico, New York: HarperCollins.

Eliade, Mircea. 1950. Le chamanisme et les techniques archaïques de l'extase, Paris: Payot.

Exnerová, Helena. 2018. Český šamanismus v rozhovorech, Praha: Dingr.

Filan, Kezan, and Raven Kaldera. 2013. Talking to the Spirits. Personal Gnosis in Pagan Religion, Rochester: Destiny Books.

FLICK, UwE. 1995. Qualitative Forschung, Reinbek: Rowohlt.

FLICK, Uwe. 1998. An Introduction to Qualitative Research, London-Newbury-Dehli: Sage.

Francfort, Henri-Paul, Hamayon, Roberte N., and Bahn, Paul G. eds. 2001. The Concept of Shamanism. Uses and Abuses, Budapest: Akademiai Kiado.

Han, Min, and Carla Cunha. 2017. The Subjectified and Subjectifying Mind, Charlotte, NC: IAP.

Hendl, Jan. 2005. Kvalitativní výzkum. Základní metody a aplikace, Praha: Portal.

Hoff Kraemer, Christine. 2012. „Gender and Sexuality in Contemporary Paganism“. Religion Compass 6 (8), 390401. doi.: https://doi.org/10.1111/i.1749-8171.2012.00367.x. 
Hoff Kraemer, Christine. 2016. Pagan Traditions: Sacralizing the Body. In Religion. Embodied Religion edited by Brintnall, Kent, 143-163. New York: Macmillan.

Kaldera, Raven 2006. Mýty a astrologie (orig. Mythastrology. Exploring Planets and Pantheons, Woodbury: Llewellyn, 2004; transl. Jarmila Vegrichtová). Praha: Volvox Globator.

Kaldera, Raven. 2007a. Wyrdwalkers: Techniques of Northern-Tradition Shamanism, Hubbarston, MA: Asphodel Press.

Kaldera, Raven. 2007b. Wightridden: Paths of Northern-Tradition Shamanism, Hubbarston, MA: Asphodel Press.

Kaldera, Raven. 2008. Hermaphrodeities: The Transgender Spirituality Workbook, Hubbarston, MA: Asphodel Press.

Kaldera, Raven. 2010. Double Edge: The Intersection of Transgender and BDSM, New York: Alfred Press.

Kaldera, Raven. 2012a. «The Third Voice». In Gender and transgender in Modern Paganism edited by Thompson, Sarah et al., 75-86. Cupertino, CA: Circle of Cerridwen.

Kaldera, Raven. 2012b. Dealing with Deities: Practical Polytheistic Theology, Hubbardston, MA: Asphodel Press.

Kaldera, Raven. 2012c. Horn and Banner. Rituals for the Northern Tradition, Hubbardston, MA: Asphodel Press.

Kaldera, Raven, and Galina Krasskova. 2012. Neolithic Shamanism: Spirit Work in the Norse Tradition, Rochester, VE: Destiny Books.

Klein, Axel, And Lucy Williams. 2012. „Immigration detention in the community: Research on the experiences of migrants released from detention centres in UK». Population, Space and Place 18 (6): 741-753. doi.: https://doi. org/10.1002/psp.1725.

LÉvi-Strauss, Claude. 1958. Anthropologie structurale, Paris: Plon.

Maiello, Giuseppe. 2015. Slavistická studia jako východisko k revitalizaci etnického nábozenství Slovanu (rodnoverí). In Aktuální problémy současné slavistiky (Jazyk-Literatura-Kultura-Politika) edited by Pospíšil, Ivo et al., 421-429. Brno: Galium.

Osvaldová Barbora. 2004. Česká média a feminismus, Praha: Slon.

Pond, Gina. 2012. «Preface». In Gender and transgender in Modern Paganism edited by Thompson, Sarah et al., v-x. Cupertino, CA: Circle of Cerridwen.

Rosenthal, Gabriele. 1995. Erlebte underzählte Lebensgeschichte. Gestalt und Strukturbiographischer Selbstbeschreibungen, Frankfurt am Main: Campus, 1995.

Ruggio, Ilenia. 2012. Il giudice antropologo. Costituzione e tecniche di composizione dei conflitti multiculturali, Milano: Franco Angeli.

Rychlíková, Apolena and Jakub Zelenka. 2021. «Chování Dominika Feriho je veřejné tajemství. Ženy popsaly traumatizující zkušenosti s mladým politikem». Deník $N$ - a2larm.cz. https://denikn.cz/633350/chovanidominika-feriho-je-verejne-tajemstvi-zeny-popsaly-traumatizujici-zkusenosti-s-mladym-politikem/; $\quad \underline{\mathrm{https}} / /$ a2larm.cz/2021/05/chovani-dominika-feriho-je-verejne-tajemstvi-zeny-popsaly-traumatizujici-zkusenosti-smladym-politikem/. (Date of retrieval: 25 May 2021).

SchüTze, Fritz. 1977. Die Technik des narrativen Interviews in Interaktionsfeldstudien, dargestellt an einem Projekt zur Erforschung von kommunalen Machtstrukturen, Bielefeld: Fakultät für Soziologie.

Thomassen, BJørn. 2009. «The uses of the meanings of liminality». International Political Anthropology 2 (1), 5-27.

Thompson, Sarah et al. 2012. Gender and Transgender in Modern Paganism, Coupertino, CA: Circle of Cerridwen Press.

Turner, Victor. 1967. «Betwixt and Between: The Liminal Period in Rites de Passage». In The forest of symbols: Aspects of Ndembu ritual edited by Turner, Victor 93-111. Ithaca, NY: Cornell University Press.

VojtíšEK, ZDENĚK. 2008. „Šamanství v Dingiru». Dingir 4: 109-135. 